\title{
気候変化の適応策としてのダムの治水・利水容量の 再配分に関する考察-紀の川流域を例として \\ DAM VOLUME REALLOCATION BETWEEN FLOOD CONTROL AND WATER USE AS AN ADAPTING POLICY UNDER CLIMATE CHANGE IN KINO RIVER BASIN
}

\author{
吉村耕平1)・小池俊雄2) \\ Kohei YOSHIMURA and Toshio KOIKE \\ 1正会員 東京大学大学院工学系研究科 特任研究員（干113-8656 東京都文京区本郷七丁目3-1) \\ 2フェロー会員 工博 東京大学大学院工学系研究科 教授（干113-8656 東京都文京区本郷七丁目3-1）
}

\begin{abstract}
Using existing stock is important to plan the adaptation policy under climate change. This study is focus on evaluation about multi purpose dam volume reallocation from water use to flood control and "trade-off" problem. In kino river basin, we input bias corrected and temporal/special downscaling 10 GCM output data to hydrological model which can represent long-term water circulation and simulate dam storage. The simulation indicates that drought risk shift is not common trend in each GCM without dam, but it will decrease mutually with dam which can storage increased flood. In addition, reallocation method enable to avoid exceedance flood or to make evaluate delay time and ease peak flow.
\end{abstract}

Key Words : Distributed hydrological discharge model, multi purpose dam, global climate model, dam volume reallocation, down scaling, bias correction, adaptation policy

\section{1. はじめに}

\section{(1)本研究の背景}

IPCC第4次評価報告書1)では大雨の頻度の増大が指摘 され，国内の答申2)でも洪水と渇水のリスクの増大につ いても指摘されており, 河川整備における適応策は重要 となってきている. 特に洪水リスクの増大から人命や資 産を守ることを求められる. しかし人口減少や財政難の 点からは新規のインフラの建設は限定的であり既存ス トックの活用も候補となる．その中でも多目的ダムの容 量の再配分という手法も存在するが，洪水制御容量への 再配分は利水容量を圧迫し渴水リスクを高める. トレー ドオフを考慮すべきであるという指摘34)もあるが，も し強雨の頻度が増大寸れば，ダムの水位回復のチャンス が増えるため，より少ない利水容量で渴水を回避でき， トレードオフの問題は緩和される可能性も考えられる. 治水・利水双方のリスクと，治水・利水の間で発生しう るトレードオフの問題を定量的に分析することが求めら れる.

\section{(2)本研究の目的と手法}

本研究の目的を，多目的ダムでの利水から洪水調節へ
の容量再配分に焦点をあてて, 洪水被害をどの程度軽減 できるか，利水へのリスクの増大がないか，さらに洪水 渇水の同時のリスクの増大や，トレードオフの関係を検 証することとする.

先のような課題を議論するには, 気候変化をシミュレー ションした全球気候モデル (GCM) のアウトプットを水文モ デルに入力し, 河川の流量の值に変換してダムの貯留量の 変動を分析する, といら研究手法が有効である.これらの研 究はすでに多くあるが，GCMのアウトプットには不確実性 があり, 水文モデルで活用するには時間的空間的解像度 が不十分であり, 観測デー夕に対しての再現性の点でバイ アスがある.

そのため, 単一のモデルの持つ不確実性を避けるため, 複数のGCMを活用し, 流域の特性や降雨強度特性に応じ た統計的ダウンスケーリング・バイアス補正を行なう. 次に長 期で高水・低水を精度よく再現できる水文モデルに, 補正さ れた気候データを入力し, 気候変化による治水上・利水上 のリスクの変化をシミュレーションする. そして適応策しして の多目的ダムの容量の再配分の影響を検証することとする. 対象流域は, 流域内での降雨特性が変化に富む紀の川と する. 


\section{(3)対象河川の概要}

対象河川の紀の川は, 日本有数の降雨地帯の奈良県南 部は大台ヶ原を源流とし, 中央構造線にそって流れ下り, 和 歌山県の北部を流れ和歌山市で紀伊水道に注ぐ幹線流路 長 $136 \mathrm{~km}$, 流域面積 $1750 \mathrm{~km}^{2}$ の一級河川である. 水害のリス クは極めて大きく, 戦後だけでも昭和 28 年の台風13号と昭 和34年の伊勢湾台風で大きな被害を受けている.

一方で紀の川は流況の不安定な河川であり, 夏期にお いては支流の貴志川では断流が発生している.このため用 水路の建設に加え利水用ダムの建設や他水系との導水な どを行い, 多目的ダムの大滝ダムが完成している. 現在の 流域水利権量は64.9m3/sであり, 大半は農業用水である.

この河川の流域特性を再現し, 気候変化が洪水の変化に 与える影響を定量的に評価するには, 大滝ダムの運用の要 となる大台ヶ原に集中寸る降雨を再現する必要がある.ま たダムの運用の変更など既存の水システムを利用し適応策 を考えるにあたっては, 治水と利水は切り離せないことを考 えると, 洪水のみならず, 低水期の流量を再現し, 利水面汃 らも検討が必要となる.

\section{GCMのバイアス補正とダウンスケーリング}

\section{(1)本研究で利用するGCM}

本研究で使用するGCMは以下の条件のアウトプットを出 力しているものとした.

・流出計算に必要な日降雨量と気象データ

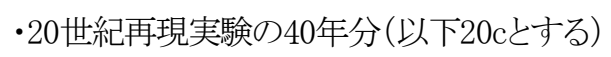

・温室効果ガス排出シナリオA1Bの 2050 年/2100年が 20 年 分(以下 $2050 y / 2100 y$ とする)

以上の条件を満たす24GCMから東アジアでの再現性を 基準5)に10モデル(表-1)を選択した. モデルの詳細は PCMDI)を参照されたい.

\section{(2)GCMの日雨量の再現性と地点別バイアス補正}

GCMの現在再現のアウトプットの再現性について, 図-1 では年総雨量を, 図-2では年最大日雨量を, GCMと地上 観測点とで比較をした. 年総水量と年最大日雨量が, 大きく 異なり. 降雨日数に関しても, 観測データと再現実験では 大きな違いがあるため, バイアス補正を行う必要がある. 流 域内での降雨特性の変化を再現するために, 降水が集中 する上流部は, 観測点網の密な国交省の観測点を, それ以 外の部分ではアメダスの観測点を用いて, 図-3のように流 域を地上雨量観測点単位でティーセン分割し, 観測点にバ イアス補正を行うことで空間的ダウンスケーリングに相当す る処理も行った.

年最大日降水量の最小值を閾值とし，それ以上の降雨 を“強雨“とここでは定義する. 図-4のように流域の中下流 部では” 強雨 “が梅雨と台風期に集中寸るが, 再現性が 低いため対象から外すgiss-aom以外はそれを再現できて いる.

本研究では洪水を引き起こす年最大日降水量をはじめ, 利水面で大きな意味を持つ2位以下から $1 \mathrm{~mm}$ といら微少な 降雨まで変換を行い, 降雨日数まで適合させることが必要 となる．20世紀再現実験と将来予測で現れた日雨量が同 じであれば, モデル上では近似した気象現象が発生してい ると考えられるため, 変換後の日雨量も同じでなければなら ない. またGCM中では, 再現実験では発生していないが, 将来は発生しうるより大きな規模の降雨も変換する必要があ る.これらを同時に満たすためにDettingerら ${ }^{7} や W o o d d^{8) ら の ~}$ 手法を利用したが,これらの研究は月ごとのグループを分 けて補正しているが, 中下流部は月ごとのグループとせ ず通年で1グループとして補正を行った。対して上流部 では図-5のように台風期に現れる降雨の強度が他の時期 に比べて卓越しているため, 台風期の7月・8月・9月と, 前 線性降雨と一部の台風がある5月・6月・10月・11月 (準洪水

\section{表-1 選択したGCM}

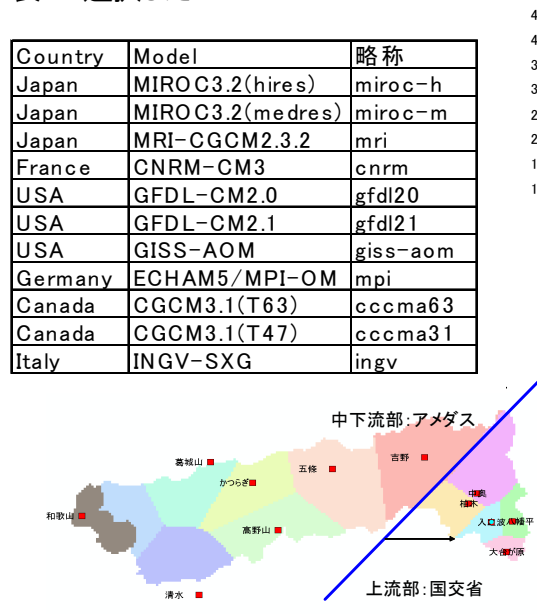

図-3 利用した流域の雨量観測点の分布

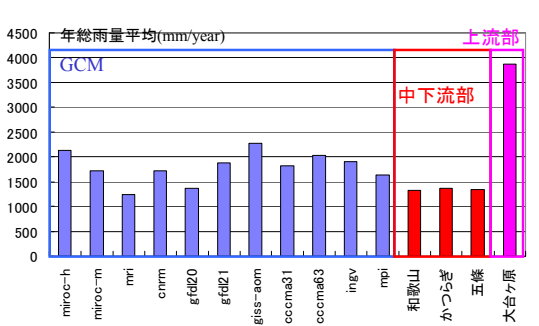

図-1 年総雨量の観測とGCMとの差異

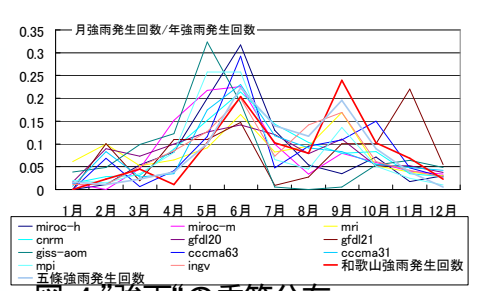

図 -4 ”强雨“の季節分布

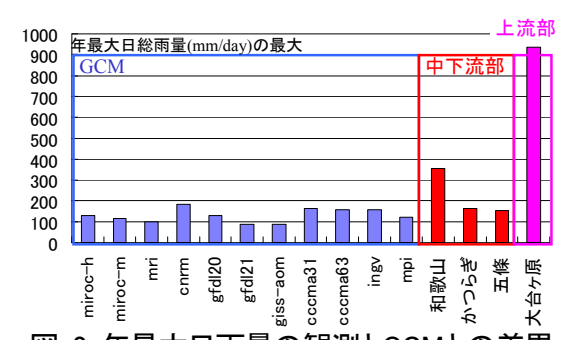

図-2 年最大日雨量の観測とGCMとの差異

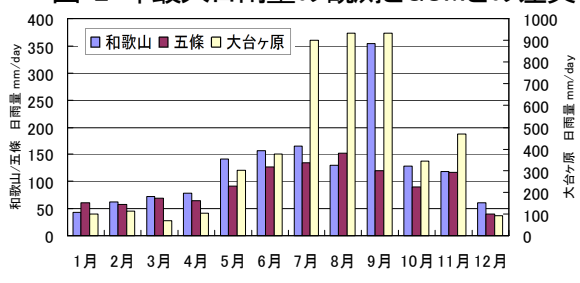

図-5 各月の最大日雨量 


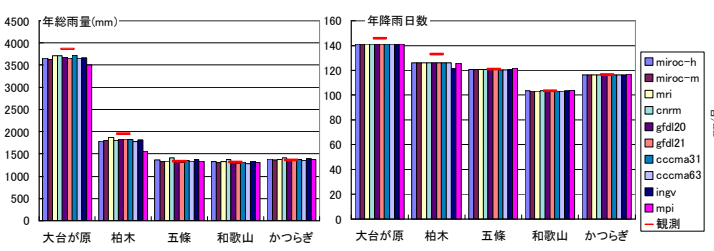

図-6 年総雨量
図-7 年降雨日数

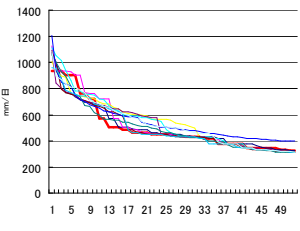

図-8 日雨量の降順曲線

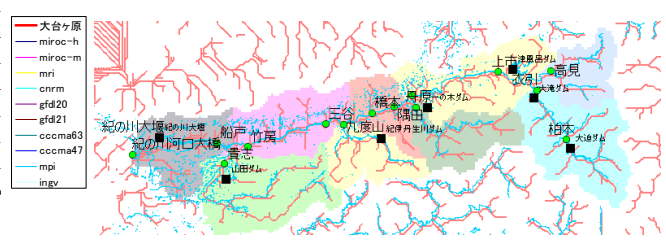

図-9 流域図(-河道-生成河道口ダム○流量観測点)
期とする)とそれ以外(非洪水期)と3つのグループに分け バイアス補正を行った.

「強雨」のバイアス補正はクオンタイルマッピングで行っ た. 上流部ではこれらの処理を 3 グループの中でそれぞれ 行うが, 非洪水期と準洪水期の「強雨」の閾值を, 年最大日 雨量の最小值ではなく中央值とした。「強雨」以外の降雨の バイアス補正は, 観測データと再現実験の降雨量を降順に ならべ, 40年換算で同順位の数值への置換を行った. 再現 実験と観測の順位を比較して, 観測の日雨量が $1 \mathrm{~mm}$ を切る 境界の順位以下の再現実験の日雨量を, 補正後の無降雨 に相当するとした.

図-6・図-7·図-8で示したとおり, 再現実験をバイアス補正 した結果, 観測データと補正結果が, 平均年総雨量・降雨 日数・大台ケ原での日雨量の降順の曲線が合致しておりバ イアス補正の効果が確認された.

\section{(3)時間的ダウンスケーリング}

洪水のリスクを分析するには日雨量から時間雨量へ時 間的ダウンスケーリングを行う必要がある. 本研究では対象 流域の特徵を再現するために, 統計的ダウンスケーリング の中でも極端值の扱いに対応が可能であるWhether generator')を利用した.

補正された日雨量を時間雨量にダウンスケーリングにす

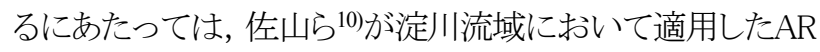
過程を用いる手法を利用したが, 紀の川流域においては観 測点ごとに年最大日雨量や強雨の頻度と規模が大きく異な るため, 各観測点の過去に経験した最も大きい日雨量の 1/20を各クラスの幅として, 計10クラス設定した.

観測点同士が近接しており, 降雨パターンの相関性が高 い上流部の国交省の観測点は, 大台ヶ原で時間雨量を生 成し, 他観測点は大台ヶ原の時間雨量を自らの日雨量を基 準にして引き延ばしを行った. また最上位クラスでの過去の 観測データから日雨量と時間雨量の最大の相関を求め, 最 大時間雨量とした. またこの上流部で過去の水害の中でも 規模の大きかった伊勢湾台風の降雨パターンを基準として, 午前中から降雨があり, 午後に降雨が強くなり, 18時に最大 雨量を迎えるパターンとした。

それ以外のアメダスの観測点については, 観測点同士で
の相関性が比較的低いため, 各観測点の独立したAR過程 による時間雨量の生成を行った。

佐山らは複数回の試行を行ったが, 本流域では洪水リス クに関しては上流部の伊勢湾台風のパターンの引き延ばし が大きな影響を与えるため, 単一の試行で十分とした.

\section{(4)気象データのダウンスケーリング}

水文モデル内で適切に蒸発散を再現させるために気象 データの時間的ダウンスケーリングを行った. 毎時の時間

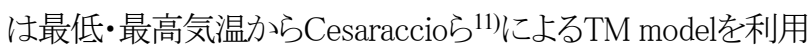
して生成した. それを元に長波放射や相対湿度など各気候 データも日データから時間データへと適宜ダウンスケーリン グを行った。

\section{3. 水文モデルについて}

\section{(1)モデルの概要}

本研究で利用する水文モデルは, 本研究室で開発され たWEB-DHM (Water and Energy Budget based-Distributed Hydrological Model) ${ }^{12)}$ である. このモデルは, 過去に開発さ れた分布型水文モデルであるGBHM (GeomorphologyBased Hydrological Model) ${ }^{13}$ に に 陸面過程モデルである SiB2 (Simple Biosphere Model2) 14)をカップリングさせたモデ ルである.

WEB-DHMは分布型水文モデルであるため, 地形・土地 利用の状況をモデル内で再現することができる. また局地 的な強雨, 言い換えれば空間的に偏りのある降雨なども再 現できるため洪水の再現に適している. さらに陸面過程と斜 面水文過程がモデルに組み込まれており, 蒸発散と土畩水 分を長期にわたって精度良くシミュレーションすることといら 利水に関して重要な点も可能で, このため降雨時のみなら ず平時の水循環特性の再現性も良いことが確認されており， 国内においても利根川上流においても検証されている15).

\section{（2）流域における水文モデルの構築と検証}

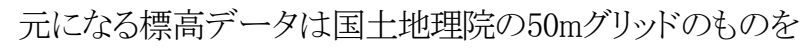
十分な精度を保ちつつ計算を高速化するため, $500 \mathrm{~m}$ 変 更してモデルを構築した(図-9). 雨量データは流域内の国 


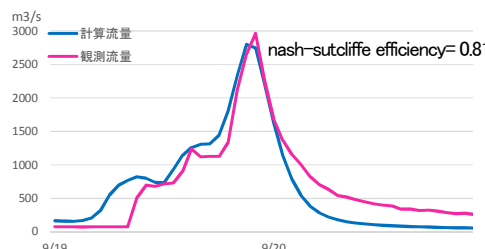

図-10 1990年の出水の計算結果

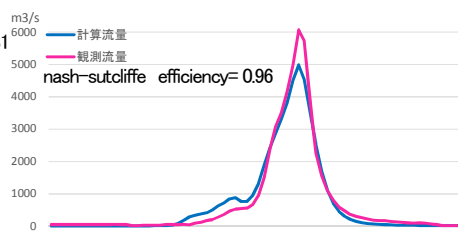

図-11 伊勢湾台風時の計算結果

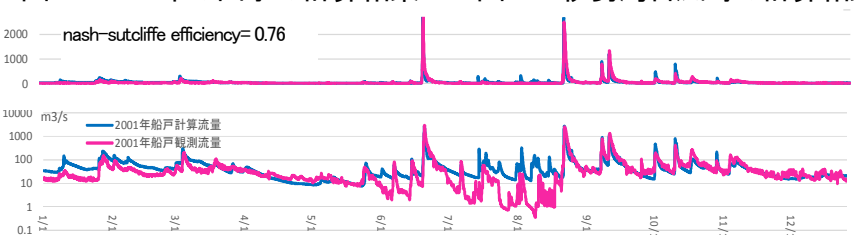

図-12 2001年の船戸における計算結果

交省・アメダスの観測点かレーダーアメダスを, 気象データ は流域内のアメダス観測点のものを利用した。

モデルのキャリブレーションと検証ししては, 近年の例とし て1990年(図-10) と既往最大とされる伊勢湾台風(図-11)に 対して, 流域内唯一の洪水制御を行う多目的ダムとなる大 滝ダムの建設地点である衣引の出水で行った. またレー ダーアメダスの精度の向上した2001年において, 通年での 船戸の流量についての結果(図-12)では, 代かき期とそれ 以降の夏季の取水による流量の大幅減少ならびに瀬切れ があり，その影響のある6月から9月を除いて ${ }^{10}$ 洪水から低 水まで十分な再現性が得られていることが確認できた.

さらにGCMのダウンスケーリング・バイアス補正の検証の ために, GCMの現在再現データから生成した雨量と観測雨 量からそれぞれ流量を計算し, その計算流量同士の日流 量の低減曲線が合致していることを確認した(図-13).

\section{4. 気候変動による流況の変化}

\section{(1) 洪水頻度と規模の変化}

船戸地点で $6,000 \mathrm{~m}^{3} / \mathrm{s}$ を超過する洪水の頻度はほぼ全て のGCMで増大している. (図-14)また衣引地点での30年確 率の洪水流量も多くのGCMで増大している(図-15). ただ

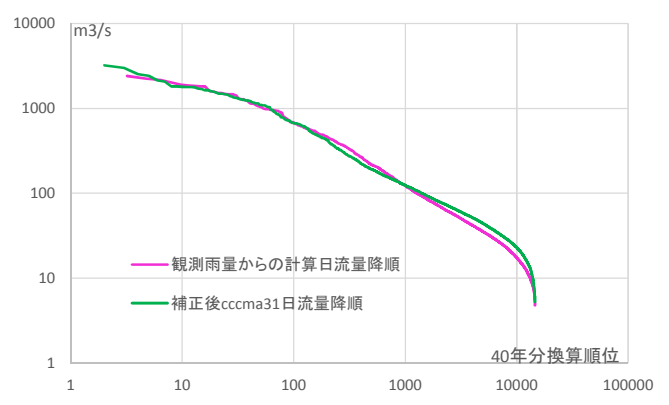

図-13 日流量の低減曲線

しgfdl21については, GCM上での最大日雨量が現在再現 の80mmから2050年では $120 \mathrm{~mm}$ と変化し, 補正後の日流量 は対数正規分布のグラフ上で $1000 \mathrm{~mm}$ から $3500 \mathrm{~mm}$ と引き 延ばされたためである.

\section{（2）渇水リスクの変化}

対象期間は後に述べる6月から9月とした. 船戸地点で 122 日中119日確保できる渴水流量の平均(図-16)につい ては, 共通の傾向は見られなかった. 水利権量に対して, 灌溉用水における還元率を半分程度として $30 \mathrm{~m}^{3} / \mathrm{s}$ 確保す べき流量とする.この流量が確保できない日数は, 多くの GCMで緩和の傾向が見られる(図-17)が, 渇水流量が減少 しつつも渇水日数は緩和されるアウトプットは，将来予測 では少数の年に現状より厳しい渴水が発生し, 統計上の渴 水流量を左右しているため緩和されないように見えるが, 他 の年では現状よりも流量が安定しており, 渇水日数が減少 しているため考えられる.

\section{5. ダムによるリスク軽減と容量再配分の検討}

\section{(1)ダム運用のシミュレーションについて}

対象期間はダムの洪水期運用の期間や, 灌溉用水の取 水期間や洪水・渴水が集中寸る6月から9月までとした. 本

表-2 ダムの容量(単位:万 $\mathrm{m}^{3}$ )

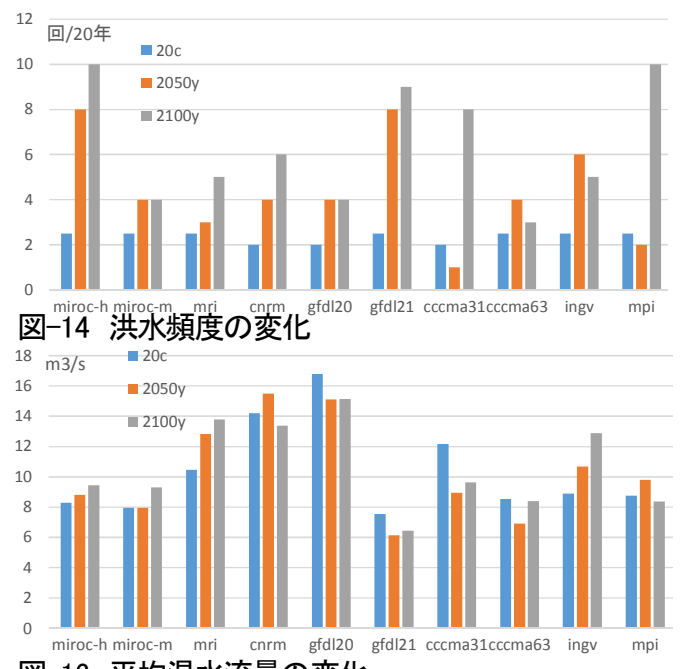

図-16 平均渇水流量の変化
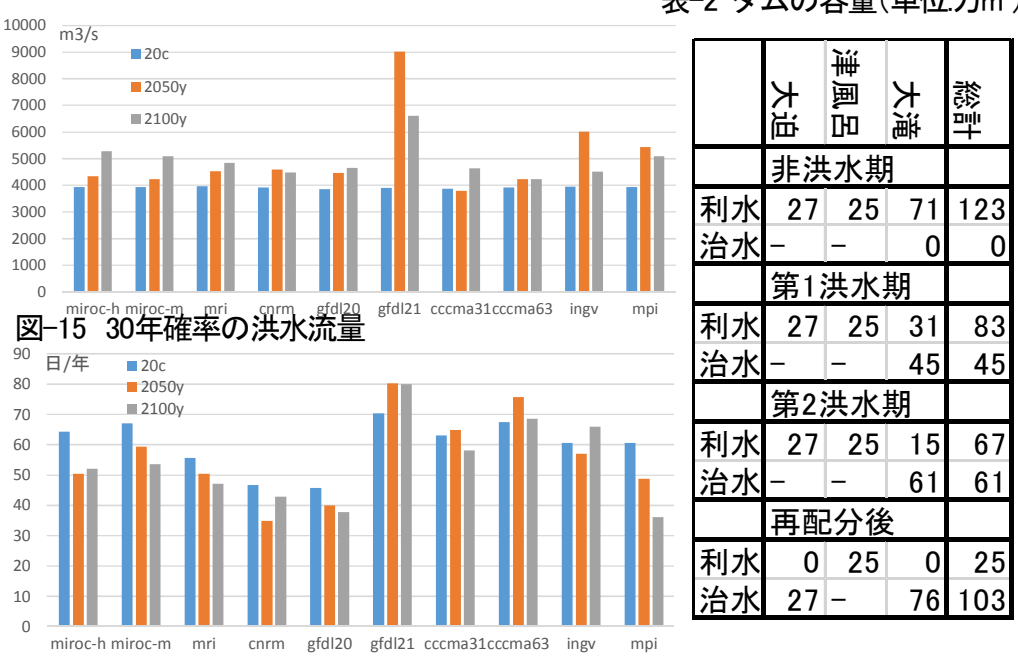

図-17 $30 \mathrm{~m}^{3} / \mathrm{s}$ を下回る日数 
流域では流域の特性で述べたとおり複数のダムが存在する が，仮想的に一つのダムを想定する. 多目的ダムである大 滝ダムは第 1 期洪水期, 第 2 期洪水期, それ以外の非洪水 期でダム容量の配分が大きく異なる(表-2). 洪水リスクが大 きい時期である第2期洪水期の運用を現状のダム容量とす る. 大台ヶ原を集水域とし, 大規模な洪水流が流入するの は本川上流(吉野川)の大迫ダムと大滝ダムである.このた め, 洪水調節容量を最大に割り振る場合には, 洪水調節容 量を 103 万的光さすことができる.

流量の基準点は河口部の船戸とし, 利水面での維持す べき流量: $30 \mathrm{~m}^{3} / \mathrm{s}$, 洪水時の河道疎通能力: $6,000 \mathrm{~m}^{3} / \mathrm{s}$, 洪 水後の放水量: $1,000 \mathrm{~m}^{3} / \mathrm{s}$ とする. ダムの運用はまず, ダム の利水容量の満水時を基準しして, $30 \mathrm{~m}^{3} / \mathrm{s}$ 下回った場合 にはダムの利水容量分から補給し，容量を使い切った場合 には次の雨まで $30 \mathrm{~m}^{3} / \mathrm{s}$ 維持できなくなる. 維持できなかっ た期間を同様に“渇水日数”として評価を行う.もし河道疎 通能力を超える洪水が発生すれば, 超過分をダムの洪水 制御容量に貯留する. 洪水後は貯水量が基準になるまで 放水する.もし貯水量が基準以下であれば, 維持すべき流 量以上分や洪水を貯留して貯水量を回復する. このため, 各洪水イベントや渇水イベント単体で分析をするよりも，「渴 水で貯水量が減少しているが, 洪水が来て貯水量が回復し た」「「渴水が断続的に発生し貯水量を回復することができ なかった」といった現象を分析できる.

\section{（2）増大する洪水リスクへの軽減効果}

現状の洪水制御容量と最大限にまで再配分を行って増 加させた洪水制御容量でゼロカッ卜操作(放流量を流入量と 同一にして貯水量を変化させない操作方法, ただし書き操 作)の回数を比較した (図-18- 図-19). 発生しうる可能性の ある超過洪水の一部に対してダムの容量再配分によりゼロ カッ操作を回避している. また再配分後でもゼロカッ卜操作
に追い込まれる場合でも, 発動を遅らせることで避難時間を 稼ぎ, 洪水のピークの後まで持ちこたえれば放水量も低下 できる. 一例としてingvの2082年の出水では, 4時間程度放 流を遅らせ, 最大放流量を $2000 \mathrm{~m} 3 / \mathrm{s}$ 程度低下できた. 以上 の点からも容量再配分は洪水リスク軽減について極めて効 果的であるといえる.

\section{(3) 渇水リスクの変化とダム容量再配分について}

現状の利水容量の $677^{3} \mathrm{~m}^{3}$ 条件で, 現在での渇水日数 と同じレベルを確保するために，将来予測ではごの利水 容量が必要なのかを計算した(図-20)。もし必要な利水 容量が減少すれば，その分の容量はトレードオフなしに 洪水制御容量に再配分できる。2050年では10GCM中5GCM が，2100年では6GCMがトレードオフなしに利水容量から 洪水制御容量に再配分できる余地があることが分かった。 再配分可能な容量は 20 万 $\mathrm{m}^{3} \sim 30$ 万 $\mathrm{m}^{3}$ 程度である. トレード オフがない範囲で再配分を行った場合では, ゼロカット操 作を回避するには至らなかったが，避難時間を確保するな どには貢献できる. また図-21では増大寸る洪水リスクに対 応するために, 洪水制御容量を増大させ利水容量を最低の 25 万ํㅜㄴ運用した場合の渴水リスクについて示す.

表-3にGCMの各アウトプットについて容量再配分に伴う 利水面でのリスクの変化やトレードオフなしでの再配分の可 能性についてまとめる.

2050年のcccma31とcccma63では, 洪水のリスクはほぼ増 えず, 渇水のリスクが高まるため, 単純なトレードオフの問 題となる. さらに双方のリスクが増大するアウトプットにおい ては, 治水安全度を確保するために, 本来ならより必要とな る利水容量を削減する必要があり, 渇水リスクの受容や他 流域からの送水，さらにコストをかけての節水などのオプ ションを検討する必要がある.この中でも特徵的な2パター ンについて述べる.

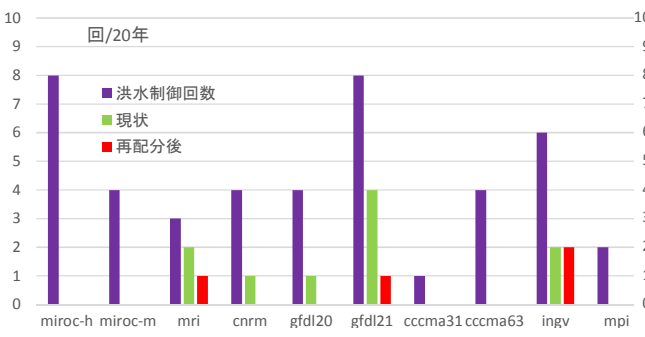

図-18 2050年におけるゼロカット操作回数

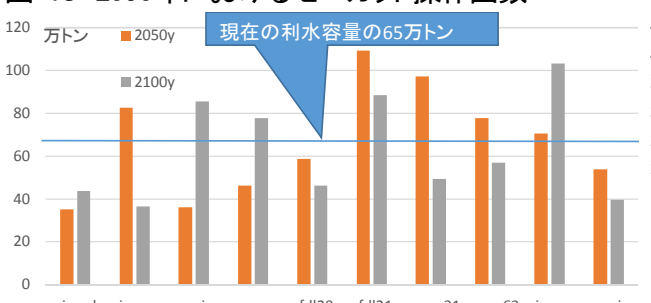

図-20 現在の渴水リスクを維持する利水容量

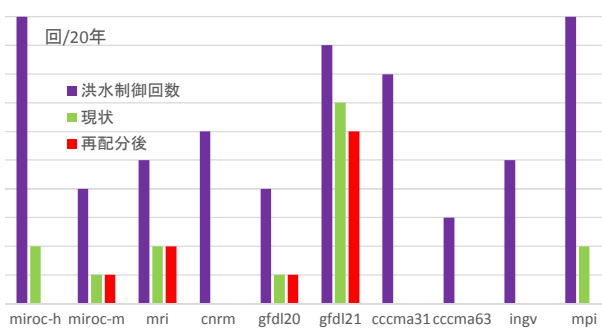

図-19 2100年におけるゼロカット操作回数

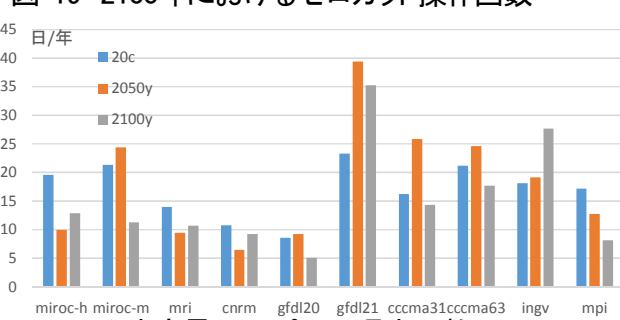

図-21 利水容量 25 万 $\mathrm{m}^{3}$ での渴水日数
表-3 容量再配分の評価

\begin{tabular}{|c|c|c|}
\hline & $2050 y$ & $2100 y$ \\
\hline miroc-h & 0 & 0 \\
\hline miroc-m & $\alpha$ & 0 \\
\hline mri & 0 & $\beta$ \\
\hline cnrm & 0 & $\beta$ \\
\hline gfdl20 & 0 & 0 \\
\hline gfdl21 & $x$ & $x$ \\
\hline cccma31 & $\triangle$ & 0 \\
\hline cccma63 & $\triangle$ & 0 \\
\hline ingv & $\alpha$ & $x$ \\
\hline $\mathrm{mpi}$ & 0 & 0 \\
\hline \multicolumn{3}{|c|}{$\begin{array}{l}\mathrm{O}: \text { 再配分可能 } \\
\times \text { : 双方のリスク増大 }\end{array}$} \\
\hline \multicolumn{3}{|c|}{$\begin{aligned} & \Delta: \text { 洪水のリスクのみ } \\
& \text { で増大でトレードオフ }\end{aligned}$} \\
\hline
\end{tabular}


miroc-mとingvの2050年では, ダムなしでは渇水日数は 減るものの必要な利水容量が増大している $(\rightarrow \alpha)$.これは 多くの年では渇水は緩和されるが，一部に今よりも深刻な 渇水が発生する年があるからである.この場合, 特定の年 の深刻な渇水に対応するオプションを考えるべきである.

同じくmriとcnrmの2100年では同じ渇水日数を確保するの には必要な利水容量は増大している.もし, 最大限に利水 容量を洪水制御容量に再配分した場合での渇水日数を比 較すると, 当然現在の渇水日数は 67 万 $\mathrm{m}^{3}$ に比して 25 万 $\mathrm{m}^{3} て ゙$ は増大寸るが, 25 万初で運用した場合の渇水日数は, 現在 よりも2100年では減少している. 現状の利水安全度を確保 するなら双方のリスクが増大することになるが，再配分する ことが前提であるならトレードオフの問題は緩和されるといら ことである. $(\rightarrow \beta)$

\section{6. おわりに}

本研究では, 紀の川流域を対象として, GCMのアウトプッ 卜を補正し流出解析に利用し, 洪水渇水少スクダムの運用 について検討を行った.

洪水リスクについては気候変化によって確率流量や洪水 頻度の増大が明確となり, 超過洪水のリスクがあることが示 唆された. またダム容量の再配分は超過洪水を回避, ある いは被害の軽減に寄与することが分かった。

また利水と渇水のトレードオフについては, 半数以上のア ウトプットでトレードオフなしに再配分できる余地があり, ト レードオフを強いられるアウトプットや双方のリスクが増大す るアウトプットよりも多いことが分かった. ダム容量の再配分 はトレードオフの問題がある程度回避出来る可能性があり, 有利なオプションになりうると判断できた.

また再配分は限定的なコストで行えることに加え，一部の GCMで2050年と2100年とで傾向が異なるように, これから の気候変化の動向が変化することも考えられ，その変化に 対して柔軟にかつ手戻りがなく最適な配分に変更が出来る ため, 適応策に求められる「順応的アプローチ」に適してい るオプションだと考えられる.

謝辞: 本研究は，文部科学省「地球観測データ統融合連携研究 機構 地球環境情報統融合プログラム（DIAS-P）」の下で行 われたものです。ここに感謝します.

\section{参考文献}

1)IPCC:IPCC第4次評価報告書,2007.

2)社会資本整備審議会:水災害分野における地球温暖化に伴う 気候変化への適応策のあり方について,2008.
3)Jeffrey T. Payne, Andrew W. Wood, Alan F. Hamlet, Richard N. Palmer and Dennis P. Lettenmaier:Mitigating the effects of climate change on the water resources of the Columbia River Basin,Climatic Change,62,233-256,2004.

4)Se-Yeun Lee, Alan F. Hamlet, Carolyn J. Fitzgerald, and Stephen J. Burges:Optimized Flood Control in the Columbia River Basin for a Global Warming Scenario,Journal of water resources planning and management, 135,440-450,2009.

5)山本弘樹:気候変動下の洪水・渇水評価のためのモデルバイ アス補正手法の開発,東京大学工学系研究科修士論文,2011.

6)PCMDI:CMIP3 Climate Model Documentation, References, and Links,http://www-pcmdi.llnl.gov/ipce/model_documentation/ ipcc_model_documentation.php, (参照 : 2012/4/23).

7)Dettinger, M.D.Cayan, D.R., Meyer, M.K., and Jeton,A.E.:Simulated hydrologic responses to climate variations and change in the Merced, Carson,and American River basins, Sierra Nevada, California,19002099, Climatic Change,62,283-317,2004.

8)Wood, A.W., Leung, L.R., Sridhar, V. and Lettenmaier,D.P.:

Hydrologic implications of dynamical and statistical approaches to downscaling climate model outputs,Climatic Change,62,189-216,2004. 9)RL Wilby, SP Charles, E Zorita, B Timbal, P Whetton, LO Mearns:Guidelines for Use of Climate Scenarios Developed from Statistical Downscaling Methods.,IPCC,2004.

10)佐山敬洋,立川康人,寶馨,増田亜美加,鈴木玩也:地球温暖化が 淀川流域の洪水と貯水池操作に及ぼす影響の評価, 水文・水資 源学会誌,Vol21(4),296-313,2008.

11)C.Cesaraccio,D.Spano,P.Duce and R. L. Snyder:An improved model for determining degree-day values from daily temperature data.International Journal of Biometeorology,Vol.45,161-169,2001.

12)Wang, L, Koike, T, Yang, K, Jackson, T, Bindlish, R. and Yang,D.:Development of a distributed biosphere hydrological model and its evaluation with the Southern Great Plains Experiments (SGP97 and SGP99),JOURNAL OF GEOPHYSICAL RESEARCH,114,2009. 13)Yang, D.:Development of a geomorphology-based hydrological model for large catchments,水工学論文集,42,169-174,1998.

14)Sellers, P.J, Randall, D.A, Collatz, G.J, Berry, J.A, Field, C.B,Dazlich, D.A, Zhang, C, Collelo, G.D. and Bounoua, L.:A Revised Land Surface Parameterization (SiB2) for Atmospheric GCMS.Part I: Model Formulation,Journal of Climate,9,676-705,1996.

15)Wang, L., T. Koike, K. Yang, and P. Yeh:Assessment of a distributed biosphere hydrological model against streamflows and MODIS land surface temperature in the upper Tone River Basin,Journal of Hydrology,337,21-34,2009.

16)第17回紀の川流域委員会配付資料:紀の川河川整備計画立案 に向けての考え方について【利水編】,2003. 